\title{
Genetic control of the protocatechuic acid pathway in Aspergillus nidulans
}

\author{
KusWANDI and C. F. ROBERTS* \\ Department of Genetics, University of Leicester, University Road. Leicester LE1 7RH, UK
}

(Received 18 November 1991; revised 13 January 1992; accepted 17 January 1992)

\begin{abstract}
The genetic analysis of 16 recessive pca mutants in Aspergillus nidulans deficient in the metabolism of protocatechuic acid (PCA) has revealed seven functional genes. The seven gene loci are distributed over three chromosomes: pcaA, pcaC and pcaD on linkage group II; pcaE, pcaF and pcaG on group $\mathrm{V}$, and pcaB on group VIII, where it shows linkage |recombination frequency $(R F)=6.9 \%$ | to the qut gene cluster controlling the degradation of quinic acid to PCA. Only two of the pca gene loci are closely linked: pcaE and pcaG $(\mathrm{RF}=0.8 \%)$. The properties of the qut and pca mutants clearly demonstrate the separate identity and regulation of the converging pathways from quinate or benzoate to PCA, which in turn is oxidatively degraded through $\beta$-ketoadipate to TCA intermediates. Similarly, the mutants are not affected in the metabolism of salicylate to catechol and its oxidation to $\beta$-ketoadipate, although two genes (pcaA and pcaF) are required for the further metabolism of $\beta$-ketoadipate. Catechol dioxygenase is induced by growth in the presence of salicylate, and PCA dioxygenase by benzoate or quinate. Three groups of pca mutants ( pcaB, pcaD and pcaE) are deficient in the induction of PCA oxygenase and accumulate PCA when grown in the presence of quinate or benzoate. All three pcaE mutants and the single pca $A$ strain totally lack PCA oxygenase activity, while a single pcaB mutant strain has properties tentatively suggesting a positive role in the induction of the PCA pathway.
\end{abstract}

\section{Introduction}

A wide variety of soil microorganisms are able to catabolize aromatic compounds (Dagley, 1971), which arise largely from the extracellular degradation of lignins (Cain, 1980). The many forms of substituted aromatic ring are transformed to metabolic intermediates converging upon central pathways in which the aromatic nucleus is cleaved oxidatively by either 'meta'- or 'ortho'fission in bacteria and by 'ortho'-fission in fungi yielding, respectively, either $\gamma$ - or $\beta$-ketoadipates which are further degraded to intermediates that enter the tricarboxylic acid cycle.

The two branches of the $\beta$-ketoadipate pathway are controlled by separate operons (Stanier \& Ornston, 1973), and operons controlling such central pathways are often themselves clustered on the bacterial chromosome in 'supra-operons' (Wheelis, 1975). In contrast, enzymes of the peripheral pathways for aromatic transformations are usually encoded by plasmid borne genes (Holloway \& Morgan, 1986). The isolation of gene clusters for cat, ben (benzoate) and pca metabolism from Acinetobacter

\footnotetext{
* Author for correspondence. Tel. (0533) 523427; fax (0533) 523489.
}

Abbreviations: PCA, protocatechuic acid; QA, quinic acid; RF, recombination frequency. calcoaceticus by their expression in Pseudomonas putida (Shanley et al., 1986) or Escherichia coli (Neidle et al., 1989; Doten et al., 1987) has enabled molecular analysis of the regulatory mechanisms. The strong likelihood of a quinate operon has not been investigated apart from the report of a quinate non-utilizing mutant strain qui-1001 of Pseudomonas putida (Wheelis \& Stanier, 1970).

An extensive survey by Cain et al. (1968) of the metabolism of aromatic acids in fungi confirmed the separate identities of the catechol and protocatechuate pathways, and demonstrated that fungi metabolize benzoate to $p$-hydroxybenzoate and then protocatechuate rather than to catechol, as is the case in bacteria. Moreover, fungi produced a $\beta$-carboxy muconolactone prior to $\beta$-ketoadipate rather than a $\gamma$-derivative. Generally, fungi show tight regulation of dioxygenase induction, and subsequent enzymes in the pathway are less rigorously controlled than in bacteria other than certain Rhizobiaceae (Parke \& Ornston, 1986). The same routes for aromatic degradation by the protocatechuate pathway have been demonstrated in the soil yeasts Rhodotorula mucilaginosa (Cook \& Cain, 1974) and Trichosporon cutaneum (Powlowski et al., 1985).

It is striking that no genetic studies have been reported on aromatic catabolism in fungi apart from the initial steps in the degradation of quinate to protocatechuate, in 
which the enzymes are highly inducible and controlled by a cluster of closely linked genes (Giles et al., 1985). Quinate is a good carbon source for growth of Aspergillus nidulans and extensive genetic and molecular analysis of the qut gene cluster has been undertaken (Grant $e t$ al., 1988; Lamb et al., 1990). In addition the control of the aromatic biosynthetic pathway has been investigated to identify molecular mechanisms regulating gene expression to produce physiological integration between potentially competing metabolic pathways (Hawkins \& Roberts, 1989; Lamb et al., 1991). Isolation and analysis of the complex gene arom $A$ from $A$. nidulans has shown an uninterrupted open reading frame encoding a single pentafunctional polypeptide catalysing steps 2 to 6 in the common pathway for aromatic biosynthesis (Charles et al., 1986), and which has probably arisen by multiple gene fusions in divergent evolution from a common ancestor (Hawkins, 1987). The question of whether the genes controlling the $\beta$-ketoadipate pathway in fungi are closely linked has not been previously addressed. A gene, bguA, affecting the utilization of both benzoic and quinic acids has been located to linkage group II in $A$. nidulans (Hynes \& Kelly, 1981).

A number of pca mutants deficient in the further metabolism of protocatechuate were recovered in the course of the isolation and analysis of quinate nonutilising mutants in $A$. nidulans (Grant et al., 1988), and the analysis of 16 pca mutants identifying seven functional genes in the $\beta$-ketoadipate pathway is reported in this communication.

\section{Methods}

Aspergillus nidulans strains. The wild-type and mutant strains, culture conditions and media were all as previously described, and conventional methods were followed in crossing strains and in the synthesis of heterozygous diploids (Grant et al., 1988). The pca genes were allocated to linkage groups by mitotic haploidization (Pontecorvo \& Kafer, 1958) using a master strain MSE ( $y A 2 ; w A 3 ;$ galA1; pyro $A 4 ;$ facA303; $s B 3$; nicB8; riboB2; McCully \& Forbes, 1965) to synthesize the heterozygous diploid strains and benomyl $\left(0.7 \mu \mathrm{g} \mathrm{ml}^{-1}\right)$ to induce mitotic haploidization (Hastie, 1970). Carbon sources were supplied at the final concentrations $20 \mathrm{~mm}$-glucose, $40 \mathrm{mM}$-glycerol and $100 \mathrm{~mm}$-acetate (at $\mathrm{pH}$ 6.5) from sterile stock solutions in distilled water autoclaved at $10 \mathrm{lbs}$ (about $70 \mathrm{kPa}$ ) pressure for $10 \mathrm{~min}$. Aromatic acids were supplied at final concentrations of $10 \mathrm{~mm}$ from stock solutions brought to $\mathrm{pH}$ 6.5-7.0 and sterilized by filtration except quinate which was autoclaved as above.

The Rothera test. This reaction tests for the accumulation of keto acids and was based upon the method of Norris \& Ribbons (1971). Mycelium grown for 14-16 h in liquid minimal medium with glucose as carbon source was harvested by filtration under sterile conditions and briefly rinsed with glucose-free medium. Samples of mycelium were then resuspended in the same growth medium containing either no carbon source (negative control) or $10 \mathrm{~mm}$ aromatic acid, and incubated for $6 \mathrm{~h}$ before they were recovered on the filter. Approximately $0.1 \mathrm{~g}$ fresh weight mycelium was resuspended in $2 \mathrm{ml} 0.02 \mathrm{M}-$ Tris/ $\mathrm{HCl}$ buffer $\mathrm{pH} 8.0$ in a glass tube and $0.5 \mathrm{ml}$ toluene was added.
The suspension was agitated periodically during a $1 \mathrm{~h}$ incubation at $30^{\circ} \mathrm{C}$ before carrying out the Rothera reaction.

Approximately $1 \mathrm{~g}$ of $\left(\mathrm{NH}_{4}\right)_{2} \mathrm{SO}_{4}$ crystals were added to each tube, followed by 1 drop (about $0.05 \mathrm{ml}$ ) of freshly prepared $1 \%(\mathrm{w} / \mathrm{v})$ sodium nitroprusside and then $0.5 \mathrm{ml} 0.880 \mathrm{sp}$. gr. ammonia. The immediate development of a deep violet colouration upon mixing indicates the presence of keto acids. Small amounts of $\beta$-ketoadipate were added in place of mycelium as a positive control.

Enzyme assays

Mycelium was grown in glucose liquid culture and resuspended in liquid growth medium with a single aromatic substrate $(0.01 \mathrm{M})$ and incubated for a further $12-16 \mathrm{~h}$. The mycelium was then recovered on the filter, rinsed with distilled water and extraction buffer $(0.1 \mathrm{M}$ potassium phosphate, pH 7.2, $10 \mathrm{~mm}$-EDTA, $1 \mathrm{~mm}$-DTT, $1 \mathrm{~mm}$ PMSF). Mycelium was stored at $-20^{\circ} \mathrm{C}$ as required and cell-free extracts prepared by grinding to a fine powder under liquid nitrogen in a cold mortar and pestel and subsequent extraction with buffer (Grant et al., 1988). Protein concentrations were estimated using the Folin reagent and bovine serum albumin standards. All enzyme assays were done in a SP 1800 recording spectrophotometer at $37^{\circ} \mathrm{C}$ following the methods described in Norris \& Ribbons (1971). Units of enzyme specific activity are $\Delta A \mathrm{~min}^{-1}(\mathrm{mg} \text { protein })^{-1}$.

PCA 3,4-dioxygenase (EC 1.13.11.3). The oxidation of PCA was followed as the decrease in $A_{290}$ in a $1.0 \mathrm{ml}$ reaction mixture containing $0.1 \mathrm{M}$-potassium phosphate buffer $\mathrm{pH} 7.0$ and $0.01 \mathrm{M}-\mathrm{PCA}$ using $25-50 \mu l$ of cell-free extract.

Catechol 1,2-dioxygenase (EC 1.13.11.1) was assayed as the formation of cis-cis-muconate which absorbs strongly at $260 \mathrm{~nm}$. The final reaction mixture was $3.0 \mathrm{ml}$ containing $2.0 \mathrm{ml} \quad 0.1 \mathrm{M}$-potassium phosphate buffer $\mathrm{pH} 7.0 ; 0.4 \mathrm{ml} 0.01 \mathrm{M}$-EDTA and $25-50 \mu \mathrm{l}$ cell free extract. The volume was brought to $2.7 \mathrm{ml}$ with distilled water and $0.3 \mathrm{ml}$ water (reference cell) or $0.3 \mathrm{ml} 0.01 \mathrm{M}$-catechol (sample cell) added to start the reaction.

\section{Results and Discussion}

\section{Genetic analysis of pca mutants}

Sixteen pca mutants identified in the isolation of qut mutants (Grant et al., 1988) were analysed. These strains grow normally with glucose or acetate as carbon source but fail to grow on quinic acid (QA) medium. They are distinct from the qut mutants since they retain overall activity of the QUT pathway producing protocatechuic acid (PCA) from QA following growth upon glycerol in the presence of QA. All of the mutants proved recessive to the wild-type in heterozygous diploid strains and complementation analysis in diploids showed that the mutants fell into seven functional groups (designated $p c a A$ to $p c a G$ ), several of which were represented by single mutant alleles ( $p c a A, 52,98,203,343 ; p c a B, 164$; pcaC, 180, 212, 226; pcaD , 198; pcaE, 120, 200, 253, 336; pcaF, 208; pcaG, 169, 244). Different mutants within each group exhibited identical phenotypic properties and a single representative strain was generally chosen for further analysis. Test crosses between the pca mutants and wild-type showed that in each case the mutant phenotype segregated as a single gene mutation. 
Table 1. Allocations of pca mutations to linkage groups by mitotic haploidization

Linked markers assort into haploid strains from the heterozygous diploids only in the two parental configurations, and the classes essentially of this pattern are shown in bold. Markers on different chromosome pairs assort into four classes.

\begin{tabular}{|c|c|c|c|c|c|c|c|c|c|c|c|c|c|c|}
\hline \multirow{2}{*}{$\begin{array}{l}\text { Linkage } \\
\text { group }\end{array}$} & \multirow{2}{*}{$\begin{array}{l}\text { Strain of } \\
\text { origin* }\end{array}$} & \multirow{2}{*}{$\begin{array}{l}\text { Known } \\
\text { markers }\end{array}$} & \multicolumn{12}{|c|}{ Number of haploids $\dagger$} \\
\hline & & & $p c a A$ & pcaA $A^{+}$ & $p c a B$ & pcaB $B^{+}$ & pcaC & pcaC $C^{+}$ & pcaD & pcaD $D^{+}$ & pcaE & pca $E^{+}$ & $p c a F$ & pcaF ${ }^{+}$ \\
\hline I & $\begin{array}{l}\text { MSE } \\
\text { R21 pca }\end{array}$ & $\begin{aligned} & y A 2 \\
\text { pabaA1 } & y A 2\end{aligned}$ & $\begin{array}{l}0 \\
0\end{array}$ & $\begin{array}{l}21 \\
22\end{array}$ & $\begin{array}{l}4 \\
7\end{array}$ & $\begin{array}{l}8 \\
6\end{array}$ & $\begin{array}{l}0 \\
0\end{array}$ & $\begin{array}{l}29 \\
20\end{array}$ & $\begin{array}{l}0 \\
0\end{array}$ & $\begin{array}{l}12 \\
26\end{array}$ & $\begin{array}{l}14 \\
13\end{array}$ & $\begin{array}{l}18 \\
10\end{array}$ & $\begin{array}{r}11 \\
9\end{array}$ & $\begin{array}{r}11 \\
8\end{array}$ \\
\hline $\mathrm{II}_{+}^{+}$ & $\begin{array}{l}\text { MSE } \\
\text { R21 pca }\end{array}$ & $w A 3$ & $\begin{array}{l}\mathbf{0} \\
0\end{array}$ & $\begin{array}{r}43 \\
0\end{array}$ & $\begin{array}{r}11 \\
0\end{array}$ & $\begin{array}{r}14 \\
0\end{array}$ & $\begin{array}{l}\mathbf{0} \\
0\end{array}$ & $\begin{array}{r}40 \\
0\end{array}$ & $\begin{array}{l}\mathbf{0} \\
0\end{array}$ & $\begin{array}{r}38 \\
0\end{array}$ & $\begin{array}{r}27 \\
0\end{array}$ & $\begin{array}{r}28 \\
0\end{array}$ & $\begin{array}{r}20 \\
0\end{array}$ & $\begin{array}{r}19 \\
0\end{array}$ \\
\hline III & $\begin{array}{l}\text { MSE } \\
\text { R21 pca }\end{array}$ & galAl & $\begin{array}{l}0 \\
0\end{array}$ & $\begin{array}{l}22 \\
21\end{array}$ & $\begin{array}{l}5 \\
6\end{array}$ & $\begin{array}{l}9 \\
5\end{array}$ & $\begin{array}{l}0 \\
0\end{array}$ & $\begin{array}{l}18 \\
22\end{array}$ & $\begin{array}{l}0 \\
0\end{array}$ & $\begin{array}{l}15 \\
23\end{array}$ & $\begin{array}{r}8 \\
19\end{array}$ & $\begin{array}{l}12 \\
16\end{array}$ & $\begin{array}{r}6 \\
14\end{array}$ & $\begin{array}{r}11 \\
8\end{array}$ \\
\hline IV & $\begin{array}{l}\text { MSE } \\
\text { R21 pca }\end{array}$ & pyroA4 & $\begin{array}{l}0 \\
0\end{array}$ & $\begin{array}{l}18 \\
25\end{array}$ & $\begin{array}{l}5 \\
6\end{array}$ & $\begin{array}{l}9 \\
5\end{array}$ & $\begin{array}{l}0 \\
0\end{array}$ & $\begin{array}{l}19 \\
21\end{array}$ & $\begin{array}{l}0 \\
0\end{array}$ & $\begin{array}{l}19 \\
19\end{array}$ & $\begin{array}{l}11 \\
16\end{array}$ & $\begin{array}{l}12 \\
16\end{array}$ & $\begin{array}{r}11 \\
9\end{array}$ & $\begin{array}{r}12 \\
7\end{array}$ \\
\hline V & $\begin{array}{l}\text { MSE } \\
\text { R21 pca }\end{array}$ & $f a c A$ & $\begin{array}{l}0 \\
0\end{array}$ & $\begin{array}{l}25 \\
18\end{array}$ & $\begin{array}{l}6 \\
5\end{array}$ & $\begin{array}{l}5 \\
9\end{array}$ & $\begin{array}{l}0 \\
0\end{array}$ & $\begin{array}{l}21 \\
19\end{array}$ & $\begin{array}{l}0 \\
0\end{array}$ & $\begin{array}{l}22 \\
16\end{array}$ & $\begin{array}{r}1 \\
26\end{array}$ & $\begin{array}{r}24 \\
4\end{array}$ & $\begin{array}{r}\mathbf{0} \\
\mathbf{2 0}\end{array}$ & $\begin{array}{r}16 \\
3\end{array}$ \\
\hline VI & $\begin{array}{l}\text { MSE } \\
\text { R21 pca }\end{array}$ & $s B 3$ & $\begin{array}{l}0 \\
0\end{array}$ & $\begin{array}{l}23 \\
20\end{array}$ & $\begin{array}{l}6 \\
5\end{array}$ & $\begin{array}{l}7 \\
7\end{array}$ & $\begin{array}{l}0 \\
0\end{array}$ & $\begin{array}{l}26 \\
14\end{array}$ & $\begin{array}{l}0 \\
0\end{array}$ & $\begin{array}{l}20 \\
18\end{array}$ & $\begin{array}{l}13 \\
14\end{array}$ & $\begin{array}{l}15 \\
13\end{array}$ & $\begin{array}{l}10 \\
10\end{array}$ & $\begin{array}{r}14 \\
5\end{array}$ \\
\hline VII & $\begin{array}{l}\text { MSE } \\
\text { R21 pca }\end{array}$ & nic $B 8$ & $\begin{array}{l}0 \\
0\end{array}$ & $\begin{array}{l}22 \\
21\end{array}$ & $\begin{array}{l}5 \\
6\end{array}$ & $\begin{array}{l}5 \\
9\end{array}$ & $\begin{array}{l}0 \\
0\end{array}$ & $\begin{array}{l}21 \\
19\end{array}$ & $\begin{array}{l}0 \\
0\end{array}$ & $\begin{array}{l}16 \\
22\end{array}$ & $\begin{array}{l}12 \\
15\end{array}$ & $\begin{array}{l}16 \\
12\end{array}$ & $\begin{array}{r}11 \\
9\end{array}$ & $\begin{array}{r}11 \\
8\end{array}$ \\
\hline VIII & $\begin{array}{l}\text { MSE } \\
\text { R21 pca }\end{array}$ & ribo 2 & $\begin{array}{l}0 \\
0\end{array}$ & $\begin{array}{l}21 \\
22\end{array}$ & $\begin{array}{r}0 \\
11\end{array}$ & $\begin{array}{r}14 \\
0\end{array}$ & $\begin{array}{l}0 \\
0\end{array}$ & $\begin{array}{l}20 \\
20\end{array}$ & $\begin{array}{l}0 \\
0\end{array}$ & $\begin{array}{l}26 \\
12\end{array}$ & $\begin{array}{l}13 \\
14\end{array}$ & $\begin{array}{l}13 \\
15\end{array}$ & $\begin{array}{r}13 \\
7\end{array}$ & $\begin{array}{r}10 \\
9\end{array}$ \\
\hline
\end{tabular}

- The haploid component strains of the heterozygous diploids were the master strain (MSE), the genotype of which is given in the text and pabaAl $y A 2$; pca (R21 pca). The mutant alleles tested were pcaA52, pcaB164, pcaC180, pcaD198, pcaE200 and pcaF208.

$\dagger$ The heterozygous diploid strains produced yellow conidiospores as the result of homozygosity for the $y A 2$ marker. Therefore only white-spored strains could be recovered upon haploidization and these were classified as haploid upon the segregation and expression of at least two of the nutritional markers. The segregation of linkage group I was followed by the marker pabaAl.

$\ddagger$ In three cases ( $p c a A, p c a C, p c a D$ ) only non-mutant $p c a^{+}$haploid segregants were recovered. Allocation of these gene loci to chromosome II is provisional based upon recovery of one class of segregants $\left(w^{\prime} A 3 p c a^{-}\right)$, since the other would have yellow spores $\left(w A^{+} p c a^{-}\right)$and thus not be identifiable. The random assortment of all seven other markers in these segregants strongly supports the location of these pca genes in linkage group Il.

When the pca mutants were inter-crossed only one pair of genes was found closely linked $p c a E$ and $p c a G$ $\left(\mathrm{RF}=0.8_{\%}^{\circ}\right.$ - two recombinant $\mathrm{QA}^{+}$progeny recovered in 500 ascospores plated). The pca mutants were also tested for linkage to the qut gene cluster, and one gene was found to map proximal to the cluster on chromosome VIII in the order pcaB164-6.9\% - qutD $312-4.4 \%$ qutRl6 with the recombination fractions shown.

Heterozygous diploid strains between representative pca mutant strains and a 'master strain' MSE (McCully $\&$ Forbes, 1965) were synthesized to allocate the pca genes to linkage groups by mitotic haploidization (Table 1). Three genes were provisionally located to linkage group II ( $p c a A p c a C p c a D$ ) and one of these most probably represents the $b g u A$ mutant of Hynes \& Kelly (1981), which was not available for analysis. Three genes were located to linkage groups $\mathrm{V}$ ( $p c a E$ and $p c a F$ : together with $p c a G$ by close linkage to $p c a E$ ), while the location of pcaB linked to the qut gene cluster on chromosome VIII was confirmed.

Thus the seven pca gene loci analysed fall to three of the eight linkage groups in $A$. nidulans, but most strikingly only two show close linkage, pcaE and pcaG (RF $0.8 \%$ ), and only one gene, $p c a B$, is linked to the qut gene cluster. This distribution of the seven pca genes stands in marked contrast to the tight linkage of all seven genes in the qut gene cluster.

\section{Further characterization of the pca mutants}

The pca mutants show reduced growth on PCA as expected and their very poor growth on benzoate or $p$-hydroxybenzoate suggests the metabolism of these compounds by the PCA pathway (Fig. 1). In addition, certain mutants produce an immediate reaction in the 'spot-test' for PCA (Grant et al., 1988) due to the prior accumulation of PCA during growth of mycelium in the presence of QA, indicating a metabolic lesion in enzyme(s) early in the PCA pathway (Table 2). Normal growth of the qut mutants on benzoate and PCA indicates separate genetic control of the QUT pathway, also reflected by normal growth of the QA non-inducible activator mutant (qutA4) and a mutant (qutD312) lacking quinate permease. The ability of all of the qut mutant strains and most of the pca mutants to grow normally on salicylate medium strongly suggests separate pathways for catechol and PCA metabolism in $A$. nidulans. Poor growth of strains pcaA52, pcaB164 and 

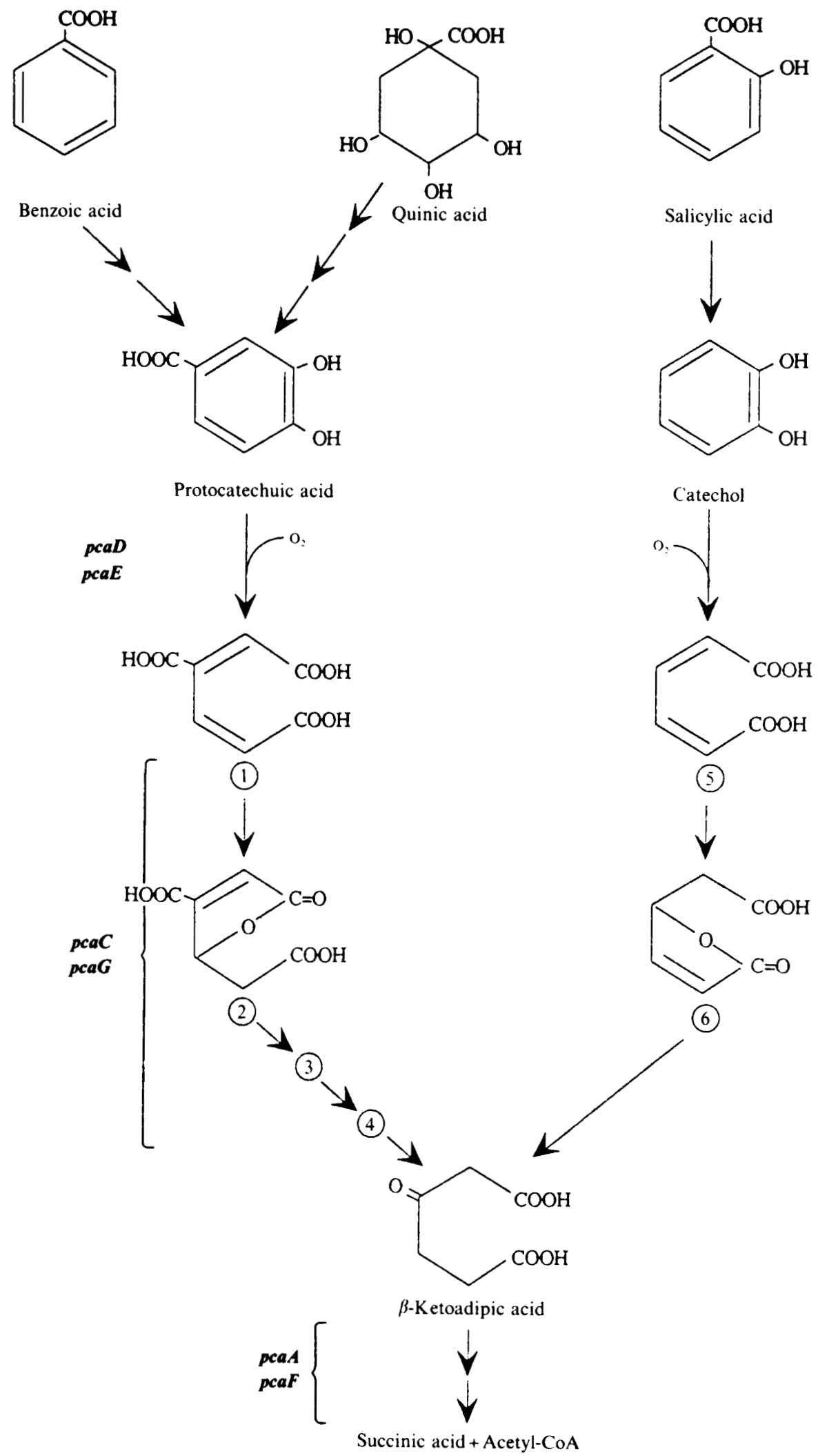
Table 2. Utilization of aromatic acids for growth by strains of $A$. nidulans

The conversion of quinic acid (QA) to protocatechuic acid (PCA) was determined by a "colorimetric spot-test' for PCA (Grant et al., 1988) applied to mycelium grown on glycerol (20 mM) agar plates in the presence of QA $(0.5 \%, w / v)$. The formation of PCA in the reaction system upon overnight incubation was recorded + and an immediate reaction $+(\mathrm{imm}$.). All aromatic acids were tested at $10 \mathrm{~mm}$ in minimal agar medium at $\mathrm{pH} 6.5$, and growth responses scored after $48 \mathrm{~h}$ incubation on a scale 0 (no growth) to 5 . In this scale growth of the wild-type on glucose would be scored 5 and on acetate 4 to reflect the different growth yields. A series of qut mutants were included for comparison and mutants qutD312,qutB42, qutE208 and qutC113 gave the same results as the non-inducible mutant qut $A 4$. The mutants are deficient in enzymes for steps 1 ( $q u t B$ ), 2 (qutE) or $3(q u t C)$ in the metabolism of QA to PCA, or in a QA permease (qutD). The mutant qut 16 is a recessive constitutive strain defective in a repressor protein (Grant et al., 1988). All strains were in the R153 (wA3; pyroA4) genetic background.

\begin{tabular}{lcccccc}
\hline \hline & & \multicolumn{5}{c}{ Carbon source for growth } \\
\cline { 3 - 7 } \multicolumn{1}{c}{ Strains } & $\begin{array}{c}\text { Conversion } \\
\text { QA } \rightarrow \text { PCA }\end{array}$ & $\begin{array}{c}\text { Quinic } \\
\text { acid }\end{array}$ & $\begin{array}{c}\text { Benzoic } \\
\text { acid }\end{array}$ & $\begin{array}{c}p \text {-Hydroxy } \\
\text { benzoic acid }\end{array}$ & $\begin{array}{c}\text { Salicylic } \\
\text { acid }\end{array}$ & $\begin{array}{c}\text { Protocatechuic } \\
\text { acid }\end{array}$ \\
\hline Wild-type (R153) & + & 4 & 4 & 4 & 2 & 3 \\
pcaA52 & + & 0 & 0 & 1 & 1 & 1 \\
pcaB164 & + & 0 & 0 & 0 & 1 & 0 \\
pcaC180 & + & 0 & 0 & 1 & 2 & 1 \\
pcaD198 & $+(\mathrm{imm})$. & 1 & 1 & 1 & 2 & 1 \\
pcaE200 & $+(\mathrm{imm})$. & 1 & 0 & 1 & 2 & 1 \\
pcaF208 & + & 0 & 0 & 1 & 1 & 0 \\
pcaG244 & + & 0 & 0 & 0 & 2 & 3 \\
qutA4 & - & 0 & 4 & 4 & 2 & 3 \\
qutR16 & + & 4 & 4 & 4 & 2 & 3 \\
\hline \hline
\end{tabular}

Table 3. Accumulation and production of keto-acid intermediates in strains of A. nidulans grown in the presence of different aromatic acids

The strains were grown in minimal medium in liquid culture for 14-16 h with glucose as carbon source. Mycelium was harvested on a filter, washed briefly with the same medium (at $37^{\circ} \mathrm{C}$ ) without glucose and resuspended in further minimal growth medium with the aromatic acids indicated at $10 \mathrm{~mm}$ and at $\mathrm{pH} 6.5$. Mycelium was collected after a further $6 \mathrm{~h}$ incubation and the Rothera test applied to samples as described in Methods. The Rothera reactions were done without added substrate (none) or with PCA or catechol at $10 \mathrm{mM}$. The qutA4 strain is described in the legend to Table 2. Strong accumulation or production of keto acids is shown + , weak $(+)$ and no accumulation -

\begin{tabular}{|c|c|c|c|c|c|c|c|}
\hline \multirow[b]{3}{*}{ Strain } & \multirow{3}{*}{$\begin{array}{l}\text { Substrate in } \\
\text { Rothera test }\end{array}$} & \multicolumn{6}{|c|}{ Aromatic acid in growth medium } \\
\hline & & \multicolumn{2}{|c|}{ Quinic acid } & \multicolumn{2}{|c|}{ Benzoic acid } & \multicolumn{2}{|c|}{ Salicylic acid } \\
\hline & & None & PCA & None & PCA & None & Catechol \\
\hline Wild-type (R153) & & - & + & - & + & - & + \\
\hline pcaA52 & & + & + & + & + & + & + \\
\hline pcaB 164 & & $(+)$ & $(+)$ & - & - & - & $(+)$ \\
\hline pcaC180 & & + & + & + & + & - & + \\
\hline pcaD198 & & - & - & - & - & - & + \\
\hline pcaE200 & & - & - & - & - & - & + \\
\hline pcaF 208 & & + & + & + & + & + & + \\
\hline pcaG244 & & + & + & + & + & - & + \\
\hline$q u t A 4$ & & - & - & - & + & - & + \\
\hline
\end{tabular}

Fig. 1 (facing page). $\beta$-Ketoadipic acid pathway in $A$. nidulans. Reactions in the metabolism of benzoic, quinic and salicylic acids to $\beta$-ketoadipic acid are indicated by arrows. Intermediates numbered are $1, \beta$-carboxy-cis,cis-muconic acid; $2, \beta$-carboxymuconolactone; 3 (hypothetical), $\gamma$-carboxy- $\beta$-ketoadipate-enol-lactone; 4 (hypothetical), $\gamma$-carboxy- $\beta$-ketoadipic acid; 5, cis,cis-muconic acid; 6 , $(+)$-muconolactone. Aromatic ring cleavage by PCA 3,4-dioxygenase and by catechol 1,2-dioxygenase are shown by $\mathrm{O}_{2}$ uptake. Genes controlling enzymes in the PCA pathway are shown. The genes $p c a D$ and $p c a E$ control PCA dioxygenase and the provisional allocation of genes controlling other enzymes is indicated. The mutant strain pca $B$ has characteristics indicating that this gene has a positive role in the induction of the enzymes of the pathway and is discussed in the text. 
pcaF 208 on benzoate, $p$-hydroxybenzoate and salicylate indicated that these mutants are deficient in enzymes below the common intermediate $\beta$-ketoadipate produced by convergence of the catechol and PCA pathways. Use of the Rothera test for the presence of keto acids supports these suggestions (Table 3). Most of the pca mutants accumulate keto acids following incubation in the presence of quinate or benzoate, suggesting metabolic lesions following aromatic ring cleavage. Moreover, the $p c a D$ and $p c a E$ mutants do not accumulate keto acids or produce them from PCA, suggesting deficiency in ring cleavage, and consistent with the observed accumulation of PCA in these strains when incubated in the presence of QA. All of the pca mutants produce keto acids from catechol following growth in the presence of salicylate, again demonstrating the separate identity of the catechol pathway.

Interestingly, strains pcaA52 and pcaF208 accumulate keto acids during growth in the presence of salicylate, indicating lesion(s) below $\beta$-ketoadipate. Strain pcaB 164 shows unusual responses and is discussed below. Absence of keto acid accumulation in the QA noninducible qut $A$ mutant and production of keto acids from PCA following induction by benzoate or from catechol by salicylate, demonstrates that the $Q U T A$ activator protein specifically regulates the QUT pathway and the $q u t$ gene cluster and is not required for induction of the PCA or catechol pathways.

\section{Induction of PCA and catechol dioxygenase activities}

Neither of the two oxygenases was detectable in glucosegrown wild-type mycelium. PCA oxygenase was induced following growth on benzoic acid $(0.26$ units specific activity) or quinic acid (0.19 units) while catechol oxygenase was induced by growth on salicylic acid $(0.25$ units). (See Methods for details of these experiments.) Although a good carbon source for growth, $p$-hydroxybenzoate was a poor inducer of PCA oxygenase $(0.08$ units) as was PCA supplied exogenously (0.06 units). Vanillate or gentisate induced no detectable PCA oxygenase activity and were also poor substrates for growth. Low levels of apparent catechol oxygenase activity found after growth with aromatic acids other than salicylate may represent very low level induction or residual activity of PCA oxygenase for catechol (data not shown). PCA oxygenase was induced by benzoate in a QA non-inducible qutA mutant (Table 4), again demonstrating pathway-specific control and strongly suggesting that PCA is the intracellular inducer of PCA oxygenase and perhaps the other enzymes of the PCA pathway.

Three groups of $p c a$ mutants were found to be deficient in PCA oxygenase activity, $p c a B, p c a D$ and $p c a E$ (Table 4). Mutants in the $p c a E$ gene (three alleles) and the single
Table 4. PCA oxygenase activities in pca mutants of A. nidulans

Mycelium of wild-type strain R153 and the mutant strains was grown in liquid culture with glucose as carbon source and subsequently incubated for $12 \mathrm{~h}$ in growth medium with the substrates shown (all at $10 \mathrm{~mm}$ and $\mathrm{pH} \mathrm{6.5)}$ ) as described in the legend to Table 2. Cell-free extracts were prepared and assayed as described in Methods. Specific enzyme activities are $\Delta A \mathrm{~min}^{-1}$ (mg protein) ${ }^{-1}$. The wavelengths were $290 \mathrm{~nm}$ for PCA oxygenase and $260 \mathrm{~nm}$ for catechol oxygenase. The specific activity values are means of three replicate assays of each extract between which good concurrence was observed. Assays done on different occasions are shown separately and grouped into the upper and lower panels of the Table. The relative enzyme activities observed in each experiment in comparison to the wild-type control (1.0) are shown in parentheses. ND, No enzyme activity detected.

\begin{tabular}{|c|c|c|c|c|}
\hline \multirow[b]{3}{*}{ Strain } & \multicolumn{3}{|c|}{ PCA oxygenase } & \multirow{3}{*}{$\begin{array}{l}\text { Catechol } \\
\text { oxygenase } \\
\text { Induced by } \\
\text { salicylic acid } \\
\text { Experiment } 4\end{array}$} \\
\hline & \multicolumn{2}{|c|}{ Induced by quinic acid } & \multirow{2}{*}{$\begin{array}{l}\text { Induced by } \\
\text { benzoic acid } \\
\text { Experiment } 3\end{array}$} & \\
\hline & Experiment 1 & Experiment 2 & & \\
\hline Wild-type & $0.121(1.00)$ & $0.143(1.00)$ & $0.067(1.00)$ & $0 \cdot 19(1 \cdot 00)$ \\
\hline $\begin{array}{l}\text { pcaA52 } \\
\text { pcaB164 } \\
\text { pcaD198 } \\
\text { pcaE200 } \\
\text { pcaE120 } \\
\text { pcaE336 }\end{array}$ & $\begin{array}{c}0.034(0.28) \\
0.002(0.02) \\
\text { ND } \\
\text { ND } \\
\text { ND } \\
\text { ND }\end{array}$ & $0.005(0.03)$ & $\begin{array}{c}0.017(0 \cdot 25) \\
\text { ND } \\
\text { ND } \\
\text { ND }\end{array}$ & $\begin{array}{l}0.10(0.53) \\
0 \cdot 17(0.89)\end{array}$ \\
\hline \multirow[t]{2}{*}{$q u t A 4$} & & ND & $0.053(0.79)$ & \\
\hline & $\begin{array}{r}\text { PCA oxy } \\
\text { Induced by } \mathrm{q} \\
\text { Experim }\end{array}$ & $\begin{array}{l}\text { genase } \\
\text { uinic acid } \\
\text { ent } 5\end{array}$ & $\begin{array}{r}\text { Catechol } \\
\text { Induced by } \\
\text { Exper }\end{array}$ & $\begin{array}{l}\text { oxygenase } \\
\text { salicylic acid } \\
\text { riment } 6\end{array}$ \\
\hline Wild-type & $0.096(1$ & $1 \cdot 00)$ & $0 \cdot 18$ & $(1 \cdot 00)$ \\
\hline $\begin{array}{l}\text { pcaC180 } \\
\text { pcaF208 } \\
\text { pcaG244 }\end{array}$ & $\begin{array}{l}0.048(0 \\
0.054(0 \\
0.024(0\end{array}$ & $\begin{array}{l}0.50) \\
0.57) \\
0.25)\end{array}$ & $0 \cdot 21$ & $(1 \cdot 17)$ \\
\hline
\end{tabular}

mutant pcaD198 had essentially no PCA oxygenase activities, very similar properties in the accumulation of PCA from QA (Table 2) and inability to form $\alpha$-keto acids from PCA (Table 3). These strains are therefore deficient in ring cleavage due to lack of PCA oxygenase but the precise roles of the $p c a D$ and $p c a E$ genes in encoding the polypeptides constituting the holoenzyme remains to be established.

The single mutant allele pcaB164 produces very low levels of PCA oxygenase activity (Table 4) and shows reduced accumulation of $\alpha$-keto acids after growth in the presence of QA (Table 3). The pcaB164 strain induces the three $Q U T$ specific enzyme activities at levels close to a wild-type strain (data not shown) and is therefore not deficient in the induction of the QUT pathway. It remains an attractive hypothesis that the $p c a B$ gene locus has a positive role in the specific induction of the PCA pathway, and the significance of linkage of the pcaB gene to the qut gene cluster remains to be explored. 
This work was in part supported by an award to Kuswandi from the World Bank Indonesia 2 Project.

\section{References}

CAIN, R. B. (1980). The uptake and catabolism of lignin-related aromatic compounds and their regulation in microorganisms. In Lignin Degradation: Microbiology. Chemistry and Potential Applications, vol. 1, pp. 21-60. Edited by T. Kent Kirk, T. Higuchi \& H. Chang. Boca Raton, Fla.: CRC Press.

Cain, R. B., Bilton, R. F. \& Darrah, J. A. (1968). The metabolism of aromatic acids by microorganisms. Biochemical Journal 108, 797-828.

Charles, I. G., Keyte, J. W., Brammar, W. J., Smith, M. \& Hawkins, A. R. (1986). The isolation and nucleotide sequence of the complex arom locus of Aspergillus nidulans. Nucleics Acid Research 14, 2201-2213

Cook, K. A. \& CAIN, R. B. (1974). Regulation of aromatic metabolism in the fungi. Metabolic control of 3-oxoadipate pathway in the yeast Rhodotorula mucilaginosa. Journal of General Microbiology 85, 37-50.

DAGLEY, S. (1971). Catabolism of aromatic compounds by microorganisms. Advances in Microbial Physiology 6, 1-42.

Doten, R. C., NGai, K. L., Mitchell, D. J. \& ORnston, L. N. (1987) Cloning and genetic organization of the pca gene cluster from Acinetobacter calcoaceticus. Journal of Bacteriology 169, 3168-3174.

Giles, N. H., Case, M. E., Baum, J., Geiver, R., Huiet, L., Patel, V. \& TYLER, B. (1985). Gene organization and regulation in the $q a$ (quinic acid). gene cluster of Neurospora crassa. Microbiological Review's 49, 338-358.

Grant, S., Roberts, C. F., Lamb, H., Stout, M. \& Hawkins, A. R. (1988). Genetic regulation of the quinic acid utilization ( $Q U T)$ gene cluster in Aspergillus nidulans. Journal of General Microbiology 134, $347-358$

Hastie, A. C. (1970). Benlate induced mitotic instability of Aspergillus diploids. Nature, London 226, 771

HaWkins, A. R. (1987). The complex AROM locus of Aspergillus nidulans: evidence for multiple gene fusions and convergent evolution. Current Genetics 11, 491-498.

Hawkins, A. R. \& RoberTs, C. F. (1989). Molecular interactions between the quinic acid catabolic and shikimate pathways in Aspergillus nidulans. In Molecular Biology of Filamentous Fungi, vol.
6, pp. 85-100. Edited by H. Nevalainen \& M. Penttila. Helsinki: Foundation for Biotechnical and Industrial Research.

Holloway, B. W. \& MORGAN, A. F. (1986). Genome organization in Pseudomonas. Annual Review of Microbiology 40, 79-105.

Hynes, M. J. \& Kelly, J. M. (1981). Threonine, quinate and glucuronic acid utilization mutants of Aspergillus nidulans. Aspergillus News Letter 15, 18-21.

Lamb, H. K., Hawkins, A. R., Smith, M., Harvey, I. J., Brown, J., TURNER, G. \& RoBerTS, C. F. (1990). Spatial and biological organization of the complete quinic acid utilization gene cluster in Aspergillus nidulans. Molecular and General Genetics 223, 17-23.

Lamb, H. K., Bagshaw, C. R. \& Hawkins, A. R. (1991). In vivo overproduction of the pentafunctional AROM polypeptide in Aspergillus nidulans affects the metabolic flux in the quinate pathway. Molecular and General Genetics 227, 187-196.

MCCUlly, K. S. \& Forbes, E. (1965). The use of p-fluorophenylalanine with 'master strains' of Aspergillus nidulans for assigning genes for linkage groups. Genetical Research 6, 352-359.

Neidle, E. L., HartNetT, C. \& Ornston, L. N. (1989). Characterizations of Acinetobacter calcoaceticus CatM, a repressor gene homologous in sequence to transcriptional activator genes. Journal of Bacteriology 171, 5410-5421.

NORRIS, J. R. \& RIBBONS, D. W. (1971). Methods in Microbiology. London: Academic Press.

Parke, D. \& Ornston, L. N. (1986). Enzymes of the $\beta$-ketoadipate pathway are inducible in Rhizobium and Agrobacterium spp and constitutive in Bradyrhizobium spp. Journal of Bacteriology 165, 288-292.

Pontecorvo, G. \& Kafer, E. (1958). Genetic analysis based upon mitotic recombination. Advances in Genetics 9, 71-104.

PowlowsKI, J. B., INGEBRAND, J. \& DAGLEY, S. (1985). Enzymology of the $\beta$-ketoadipate pathway in Trichosporon cutaneum. Journal of Bacteriology 163, 1136-1141.

Shanley, M. S., Neidle, E. L., Parales, R. E. \& Ornston, L. N. (1986). Cloning and expression of Acinetobacter calcoaceticus cat BCDE genes in Pseudomonas putida and Escherichia coli. Journal of Bacteriology 165, 557-563

StaniER, R. Y. \& ORNSTON, L. N. (1973). The $\beta$-ketoadipate pathway. Advances in Microbial Physiology 9, 89-150.

WhEELIS, M. L. (1975). The genetics of dissimilatory pathways in Pseudomonas. Annual Review of Microbiology 29, 505-524.

Wheelis, M. L. \& Stanier, R. Y. (1970). The genetic control of dissimilatory pathways in Pseudomonas putida. Genetics 66, 245-266. 